\title{
Jamur Makroskopis di Kawasan Hutan Lindung Reko Kecamatan Dabun Gelang Kabupaten Gayo Lues
}

\author{
Macroscopic Fungi in the Reko Protected Forest in Dabun Gelang \\ Sub-district of Gayo Lues Regency \\ Rena Fitri $^{1}$, Iswadi ${ }^{2}$, Samingan $^{3}$ \\ Program Studi Pendidikan Biologi Fakultas Keguruan dan Ilmu Pendidikan \\ Universitas Syiah Kuala Darussalam, Banda Aceh \\ Email: renafitri.bio16@fkip.unsyiah.ac.id
}

\begin{abstract}
Abstrak
Penelitian ini bertujuan untuk mengidentifikasi jamur makroskopis di kawasan hutan lindung Reko Kecamatan Dabun Gelang Kabupaten Gayo Lues dan mengetahui jamur makroskopis yang dapat dikonsumsi, tidak dapat dikonsumsi dan beracun. Penelitian ini mengunakan pendekatan kualitatif, dengan jenis penelitian deskriptif. Pengumpulan data dilakukan dengan metode survey eksploratif dengan pengambilan sampel secara subjektif. Lokasi penelitian terbagi menjadi tiga stasiun, Stasiun I kawasan kaki gunung, Stasiun II kawasan lereng gunung dan Setasiun III mewakili kawasan puncak gunung dengan masing-masing stasiun terdapat 3 transek. Data dianalisis secara deskriptif yang meliputi deskripsi jamur, gambar dan hirarki taksonomi. Hasil penelitian ditemukan sebanyak 38 spesies jamur makroskopis yang diklasifikasikan kedalam 2 divisi, 7 ordo, dan 19 familia. Spesies jamur makroskopis yang paling banyak ditemukan berasal dari ordo Polyporales dan Agaricales masing-masing sebanyak 16 speies. Empat spesies termasuk kedalam jamur konsumsi, sembilan belas spesies jamur tidak dapat dikonsumsi dan dua spesies jamur beracun.
\end{abstract}

Kata Kunci : Jamur Makroskopis, Kawasan Hutan Lindung Reko

\begin{abstract}
The aims of this research were to identify the macroscopic fungi in Reko Protected Forest in Dabun Gelang Sub-district of Gayo Lues Regency and to determine the edible, non-edible, and poisonous macroscopic fungi. This study was descriptive research with a qualitative approach. The data were collected using exploratory survey method and subjective sampling method. The location of the study was divided into three stations. The first station was the foothill, the second was the slope, and the third was the mountain peak, and each station had 3 transects. The data were analyzed descriptively, which included fungi's descriptions, pictures, and taxonomic hierarchy. The results showed that 38 macroscopic fungal species were found and classified into 2 divisions, 7 orders, and 19 families. The most commonly found species were Polyporales and Agaricales orders, with 16 species each. Four species were determined as edible fungi, nineteen species were non-edible, and two species were poisonous fungi.
\end{abstract}

Keyword: Macroscopic Fungi, Reko Protected Forest 


\section{PENDAHULUAN}

Kabupaten Gayo Lues berada pada ketinggian 100-3000 meter di atas pemukaan laut (mdpl), memiliki kawasan hutan yang sangat luas terdiri dari hutan lindung, produksi, dan pemukiman. Total luas hutan lindung 406,638 $\mathrm{Ha}$, hutan produksi mencapai 122,84 $\mathrm{Ha}$, dan pemukiman 42,47 Ha. Salah satu hutan yang terdapat di Gayo Lues yaitu hutan Reko (Badan Pusat Statistik Kabupaten Gayo Lues, 2019).

Hutan Reko terdiri dari hutan primer dan hutan sekunder, kawasan hutan Reko termasuk ke dalam hutan lindung yang menjadi penyangga ketersediaan air bersih bagi beberapa kecamatan yang berada di Kabupaten Gayo Lues. Namun keberadaan hutan semakin berkurang dengan perluasan perkebunan oleh masyarakat sekitar. Khayati dan Hadi, (2016) Penebangan dan perusakan hutan dapat menyebabkan perubahan kondisi biotik dan abiotik di suatu kawasan, penebangan pohon dapat menyebabkan banyaknya intensitas cahaya yang masuk akan membuat tanah dan serasah-serasah daun tidak ternaungi menjadi kering beberapa organisme tidak dapat tumbuh dengan baik seperti jamur makroskopis. Jamur makroskopis biasa tumbuh pada kondisi lingkungan yang teduh memiliki tingkat kelembaban tinggi, dan pencahayaan yang cukup, kondisi ini cocok untuk pertumbuhan jamur makroskopis (Hidayati dan Asmawati, 2015)

Jamur makroskopis adalah salah satu komponen penting bagi ekosistem hutan. Peran jamur makroskopis sebagai pengurai yang mempercepat siklus materi dalam ekosistem hutan yang berperan penting sebagai pendaur ulang nutrisi. Jamur makroskopis dapat ditemukan di berbagai bahan organik seperti tanah, kayu, serasah, dan kotoran hewan (Widhiastuti dan Nurtjahja, 2013).

Beberapa jenis jamur makroskopis dapat dimanfaatkan sebagai sumber bahan makanan, obat-obatan tradisional maupun modern. Jamur memiliki manfaat salah satunya dapat dikonsumsi karena mengandung nutrisi yang tinggi namun ada jenis jamur yang tidak dapat dikonsumsi karena mengandung racun (Parjimo dan Andoko, 2007). Hasil penelitian yang dilakukan oleh Taurina, (2019) bahwa ditemukan sebanyak 45 spesies jamur makroskopis yang diklasifikasi kedalam 2 divisi, 7 ordo dan 18 familia. 45 spesies jamur yang telah diidentifikasi, 5 spesies termasuk kedalam jenis jamur yang dapat dikonsumsi, 21 spesies tidak dapat dikonsumsi dan 4 jenis jamur beracun. Keanekaragaman jamur makroskopis yang terdapat di kawasan hutan Payal Rebol Kecamatan Bener Kelipah Kabupaten Bener Meriah termasuk kategori tinggi.

Berdasarkan survey di Kawasan Hutan Lindung Reko Kecamatan Dabun Gelang dengan adanya perubahan lingkungan di hutan Reko dikhawatirkan akan terjadi perubahan keberadaan jamur makroskopis di kawasan tersebut, sehingga perlu dilakukan penelitian yang berjudul "Jamur Makroskopis di Kawasan Hutan Lindung Reko Kecamatan Dabun Gelang Kabupaten Gayo Lues".

\section{METODE PENELITIAN}

Pendekatan dan Jenis Penelitian Pendekatan yang digunakan dalam 
penelitian adalah pendekatan kualitatif Jenis penelitian yang digunakan adalah survey eksploratif di Kawasan Hutan Lindung Reko Kecamatan Dabun Gelang Kabupaten Gayo Lues.

\section{Tempat dan Waktu Penelitian}

Penelitian dilakukan di Kawasan Hutan Lindung Reko Kecamatan Dabun Gelang Kabupaten Gayo Lues dan berlangsung sejak Bulan Oktober sampai dengan Desember Tahun 2020.

\section{Objek Penelitian}

Semua jenis jamur makroskopis yang terdapat di kawasan hutan lindung Reko Kecamatan Dabun Gelang Kabupaten Gayo Lues.

\section{Alat dan Bahan}

Alat yang digunakan ialah Alat tulis, Kamera Canon EOS 60D, Thermometer hermes $0-200^{\circ} \mathrm{C}$, Higrometer, Soil tester, Timestamp Camera Free, Pisau, Meteran, Penggaris/mistar, Aplikasi Mushroom Identify-Automatic Picture. Bahan, Alkohol 70 \%, Kertas lebel, Botol koleksi, Plastik.

\section{Teknik dan Prosedur Pengumpulan \\ Data}

Penentuan wilayah penelitan di kawasan hutan lindung Reko Kecamatan Dabun Gelang Kabupaten Gayo Lues dibagi manjadi 3 stasiun. Stasiun I kawasan yang mewakili kaki gunung stasiun II kawasan yang mewakili lereng gunung dan stasiun III kawasan yang mewakili bagian puncak gunung.

Pengambilan sampel dilakukan dangan (survey eksploratif). Pada setiap stasiun yang telah ditentukan dibuat transek sebagai jalur pedoman dalam pengamatan jamur. Dalam setiap stasiun terdapat 3 transek dengan panjang 100 meter dangan lebar 50 meter bidang pengamatan kanan dan kiri yang diletakkan secara subjektif apabila ditemukan jenis jamur pada jalur yang dilalui.

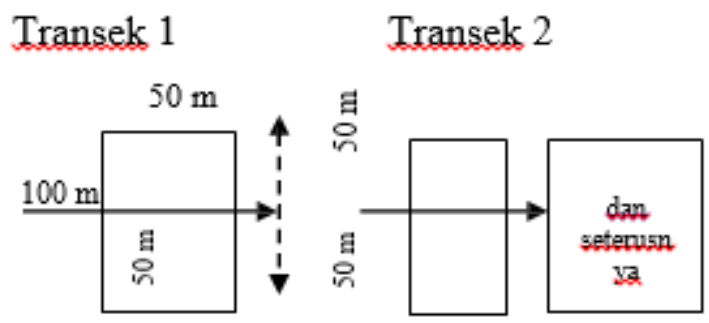

\section{Gambar 1. Denah transek garis} (Sumber: Taurina, 2019)

\section{Keterangan:}

$\square=$ Plot yang diletakkan secara subjektif

I = Garis Transek

\= Jarak jelajah ke kiri dan ke kanan

Pengumpulan sampel jamur yang ditemukan diamati, lalu didokumentasi (difoto) untuk Identifikasi lebih lanjut. Sampel jamur yang tidak dapat diidentifikasi secara langsung, maka diambil dari substratnya dengan menggunakan pisau, kemudian untuk jenis sampel jamur yang kering dimasukkan kedalam kantong plastik dan disemprot dengan alkohol $70 \%$ sedangkan untuk sampel jamur yang bersifat basah atau lunak dimasukkan kedalam botol koleksi dan diberi alcohol 70\%. Selanjutnya diberi label sesuai plot dan stasiun ditemukannya jamur.

Identifikasi sampel dilakukan dengan mengamati karakteristik jamur seperti bentuk tudung, warna tudung, permukaan atas tudung, permukaan bawah tudung, tepi tudung, bentuk lamela, warna lamela, letak tangkai, diameter, testur dan 
substrat tumbuh. Beberapa jamur yang tidak memiliki bentuk lamella dan warna lamella maka tetap diamati dengan bagian karakteristik lainnya. Sampel spesies jamur yang diperoleh dilakukan identifikasi dengan mencocokan spesies jamur tersebut menggunakan buku identifikasi Field Guide of fungi aplikasi Mushroom IdentifyAutomatic Picture Recognition untuk identifikasi jenis jamur. Untuk aplikasi Mushroom dimana kawasan yang memiliki koneksi jaringan data akan langsung diidentifikasi jenis jamurnya hanya dengan mengarahkan kamera hanphone ke jamur maka akan diidentifikasi secara otomatis. Sedangka kawasan yang tidak ada koneksi jaringan maka akan digunakan gambar jamur yang telah diambil terlabih dahulu gambarnya di upload saat menggunakan aplikasi tersebut, secara otomatis spesies

\section{HASIL DAN PEMBAHASAN}

Hasil penelitian spesies jamur makroskopis di Kawasan Hutan Lindung Reko Kecamatan Dabun Gelang Kabupaten Gayo Lues, spesies jamur makroskopis jamur yang sesuai dengan gambar akan muncul dan dikuatkan dengan website www.fungikingdom.net,www.gbif. org dan www.first-nature.com.

Pengukuran Faktor Fisik Lingkungan Dilakukan pada setiap setasiun berdasarkan ketinggian lokasi penelitian mdpl, yaitu setasiun I berada pada kaki gunung, stasiun ke II berada pada lereng gunung dan setasiun ke III berada pada puncak gunung. Adapun yang diukur meliputi suhu udara $\left({ }^{\circ} \mathrm{C}\right)$, kelembaban udara (\%), pH tanah, suhu tanah $\left({ }^{\circ} \mathrm{C}\right)$ kelembaban tanah (\%) dan ketinggian (mdpl).

\section{Analisis Data}

Analisis secara deskriptif dengan menjabarkan deskripsi jamur, ciri jamur makroskopis ditampilkan dalam bentuk tabel, dan hirarki taksonomi.

yang ditemukan dilokasi penelitian sebanyak 38 spesies terdiri dari 2 divisio, 7 ordo dan 19 Familia. Data spesies jamur makroskopis yang ditemukan dapat dilihat pada Tabel 1.

Tabel 1 Spesies Jamur Makroskopis di Kawasan Hutan Lindung Reko Kecamatan Dabun Gelang Kabupaten Gayo Lues

\begin{tabular}{|c|c|c|c|c|c|c|c|}
\hline \multirow{2}{*}{ No } & \multirow{2}{*}{ Divisi } & \multirow{2}{*}{ Ordo } & \multirow{2}{*}{ Familia } & \multirow{2}{*}{ Spesies } & \multicolumn{3}{|c|}{ Stasiun } \\
\hline & & & & & 1 & & 3 \\
\hline \multirow[t]{2}{*}{1} & \multirow[t]{2}{*}{ Ascomycota } & \multirow[t]{2}{*}{ Xylariales } & Hypoxylaceae & Daldinia con centric (Bolton) Ces \& De Not) & - & & - \\
\hline & & & Xylariacea & Xylaria polymorpha (Pres.) Grev. & & & \\
\hline \multirow[t]{17}{*}{2} & Basidiomycota & Auriculariales & Auriculariaceae & Auricularia aulicular-judae (Bull) J. Schr & & & - \\
\hline & & \multirow{16}{*}{ Agaricales } & Schizophyllaceae & Schizophyllum commune $\mathrm{Fr}$ & - & & \\
\hline & & & Tricholomataceae & Pleurotus ostreatus Jacq. P. Kummer & & & - \\
\hline & & & Physalacriaceae & Oudemansiella mucida Heinrich Adoif Schrader & & & - \\
\hline & & & Strophariaceae & Gymnopilus fulgens (J. Favre \& Maire) Singer & & & - \\
\hline & & & \multirow[t]{12}{*}{ Psathyrellacea } & Coprinellus disseminatus (Pers.) J.E. Lange & & & - \\
\hline & & & & Coprinellus micaceus (Bull) Fr & - & -1 & \\
\hline & & & & Coprinus comatus (O. F. Mull) Persoon & - & & $v$ \\
\hline & & & & Leucocoprinus birnbaumii (Corda) Singer & $\mathrm{v}$ & & - \\
\hline & & & & Agaricus moelleri Wasser & $\sqrt{ }$ & & - \\
\hline & & & & Chlorophyllum $s p$ & - & & $\checkmark$ \\
\hline & & & & Crucibulum leave (Hudsoon) Kambly & - & & $\sqrt{ }$ \\
\hline & & & & Lycoperdon pyriforme Schaef & - & & $\mathrm{v}$ \\
\hline & & & & Crepidotus malachius & - & & $v$ \\
\hline & & & & Baeospora myosura (Fr.) Singer & - & & $\sqrt{ }$ \\
\hline & & & & Marasmius androsaceus $(\mathrm{L}) \mathrm{Fr}$ & - & & $\checkmark$ \\
\hline & & & & Hemimycena candida (Bres) Singer & - & & $\mathrm{v}$ \\
\hline & & \multirow{2}{*}{ Polyporales } & \multirow[t]{2}{*}{ Ganodermataceae } & Ganoderma apllanatum P.Karst & - & & \\
\hline & & & & Ganoderma sp & & & - \\
\hline
\end{tabular}




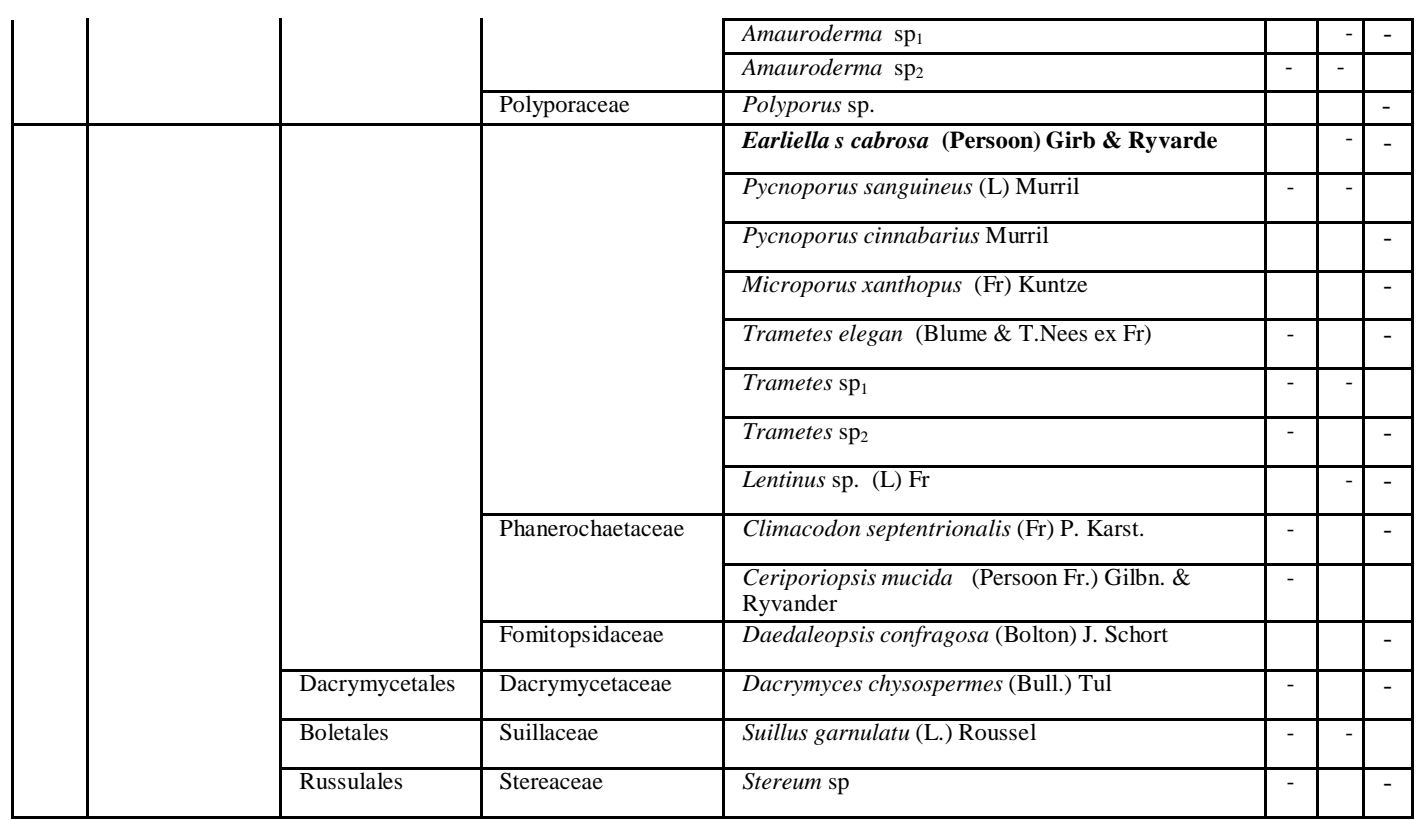

Keterangan : Stasiun (1) kaki gunung ditemukan 15 spesies, stasiun (2) lereng gunung ditemukan 24 spesies, dan stasiun (3) puncak gunung ditemukan 18 spesies jamur makroskopis.

Pada Tabel 1 spesies ordo yang paling banyak pada setiap stasiun adalah ordo Polyporales dan Agaricales masingmasing memproleh 42\%. Persentase Ordo dan Familia dapat dilihat pada Gambar 1 dan gambar 2.

\section{Persentase Jamur Makroskopis}

Berdasarkan Ordo dan Familia.

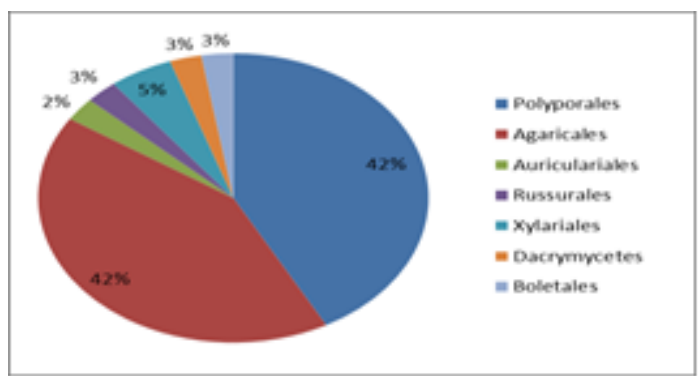

Gambar 1. Persentase Jamur Makroskopis Berdasarkan Ordo

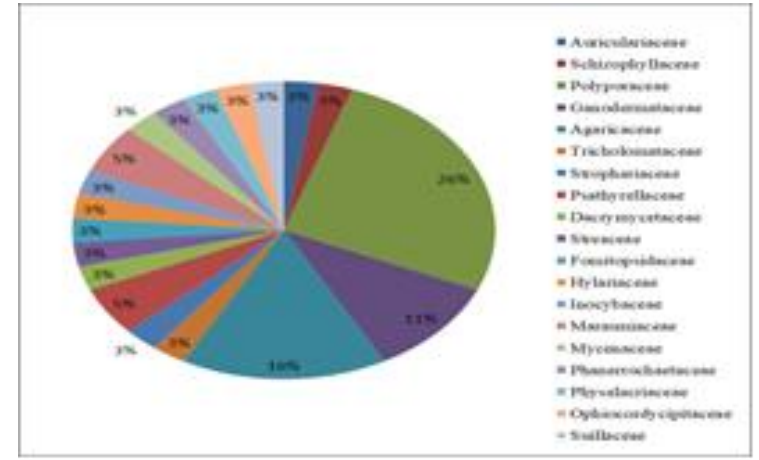

Gambar 2. Persentase Jamur Makroskopis Berdasarkan Familia.

Berdasarkan hasil penelitian di Kawasan Hutan Lindung Reko Kecamatan Dabun Gelang Kabupaten Gayo Lues beberapa spesies jamur makroskopis dapat dikonsumsi namun ada beberapa spesies termasuk kedalam kelompok jamur yang tidak dapat dikonsumsi atau jamur beracun. Data spesies jamur dikonsumsi dan jamur beracun dapat dilihat pada Tabel 2 .

Tabel 2 Spesies Jamur Makroskopis Dikonsumsi, Tidak Dapat Dikonsumsi dan Beracun di Kawasan Hutan Lindung Reko Kecamatan Dabun Gelang Kabupaten Gayo Lues

\begin{tabular}{|l|l|l|c|c|c|}
\hline No & \multicolumn{1}{|c|}{ Nama Spesies } & \multicolumn{1}{c|}{ Ordo } & Dikonsumsi & $\begin{array}{c}\text { Tidak dapat } \\
\text { Dikonsumsi }\end{array}$ & Beracun \\
\hline $\mathbf{1}$ & Daldinia con centric (Bolton) Ces \& De Not) & Xylariales & - & & - \\
\hline $\mathbf{2}$ & Xylaria polymorpha (Pres.) Grev. & Xylariales & - & - & - \\
\hline $\mathbf{3}$ & Auricularia aulicular-judae (Bull) J. Schr & Agaricales & & - & - \\
\hline $\mathbf{4}$ & Schizophyllum commune Fr & Auriculariales & & - & - \\
\hline $\mathbf{5}$ & Pleurotus ostreatus Jacq. P. Kummer & Agaricales & & - & - \\
\hline $\mathbf{6}$ & $\begin{array}{l}\text { Oudemansiella mucida Heinrich Adoif } \\
\text { Schrader }\end{array}$ & Agaricales & - & - & - \\
\hline $\mathbf{7}$ & Gymnopilus fulgens (J. Favre \& Maire) & Agaricales & - & - & \\
\hline
\end{tabular}




\begin{tabular}{|c|c|c|c|c|c|}
\hline 8 & Coprinellus disseminatus (Pers.) J.E . Lange & Agaricales & - & - & - \\
\hline 9 & Coprinellus micaceus (Bull) Fr & Agaricales & - & & - \\
\hline $\mathbf{1 0}$ & Coprinus comatus (O. F. Mull) Persoon & Agaricales & - & - & - \\
\hline 11 & Leucocoprinus birnbaumii (Corda) Singer & Agaricales & - & - & - \\
\hline 12 & Agaricus moelleri Wasser & Agaricales & - & - & - \\
\hline 13 & Chlorophyllum sp & Agaricales & - & - & - \\
\hline 14 & Crucibulum leave (Hudsoon) Kambly & Agaricales & - & - & - \\
\hline 15 & Lycoperdon pyriforme Schaef & Agaricales & & - & - \\
\hline 16 & Crepidotus malachius & Agaricales & - & - & - \\
\hline 17 & Baeospora myosura (Fr.) Singer & Agaricales & - & - & - \\
\hline 18 & Marasmius androsaceus (L) Fr & Agaricales & - & - & \\
\hline 19 & Hemimycena candida (Bres) Singer & Agaricales & - & - & - \\
\hline 20 & Ganoderma apllanatum P.Karst & Polyporales & - & & - \\
\hline 21 & Ganoderma sp & Polyporales & - & & - \\
\hline 22 & Amauroderma sp1 & Polyporales & - & & - \\
\hline 23 & Amauroderma $\mathrm{sp} 2$ & Polyporales & - & & - \\
\hline 24 & Polyporus sp. & Polyporales & - & - & - \\
\hline 25 & Earliella s cabrosa (Persoon) Girb \& Ryvarde & Polyporales & - & & - \\
\hline 26 & Pycnoporus sanguineus $(\mathrm{L})$ Murril & Polyporales & - & & - \\
\hline 27 & Pycnoporus cinnabarius Murril & Polyporales & - & & - \\
\hline 28 & Microporus xanthopus (Fr) Kuntze & Polyporales & - & & - \\
\hline 29 & Trametes elegan (Blume \& T.Nees ex Fr) & Polyporales & - & & - \\
\hline 30 & Trametes $\mathrm{sp} 1$ & Polyporales & - & & - \\
\hline 31 & Trametes $\mathrm{sp} 2$ & Polyporales & - & & - \\
\hline 32 & Lentinus sp. (L) Fr & Polyporales & & - & - \\
\hline 33 & Climacodon septentrionalis (Fr) P. Karst. & Polyporales & - & - & - \\
\hline 34 & $\begin{array}{l}\text { Ceriporiopsis mucida (Persoon Fr.) Gilbn. \& } \\
\text { Ryvander }\end{array}$ & Polyporales & - & - & - \\
\hline 35 & Daedaleopsis confragosa (Bolton) J. Schort & Polyporales & - & & - \\
\hline 36 & Dacrymyces chysospermes (Bull.) Tul & Dacrymycetales & - & & - \\
\hline 37 & Suillus garnulatu (L.) Roussel & Boletales & - & - & - \\
\hline 38 & Stereum sp & Russulales & - & & - \\
\hline
\end{tabular}

Keterangan: = Sudah diketahui

$$
\text { - = Belum diketahui }
$$

Tabel 3 Faktor Lingkungan di Lokasi Penelitian

\begin{tabular}{ccccccc}
\hline Stasiun & $\begin{array}{c}\text { Suhu } \\
\text { udara } \\
\left({ }^{\circ} \mathrm{C}\right)\end{array}$ & $\begin{array}{c}\text { Kelembaban } \\
\text { udara }(\%)\end{array}$ & $\begin{array}{c}\mathrm{pH} \\
\text { tanah }\end{array}$ & $\begin{array}{c}\text { Suhu } \\
\text { Tanah } \\
\left({ }^{\circ} \mathrm{C}\right)\end{array}$ & $\begin{array}{c}\text { Kelembaban } \\
\text { tananh }(\%)\end{array}$ & $\begin{array}{c}\text { Ketinngian } \\
(\text { mdpl })\end{array}$ \\
\hline I & 26 & 65 & 6 & 21 & 22 & 1.700 \\
\hline II & 22 & 71 & 6,9 & 17 & 10 & 1.750 \\
\hline III & 24 & 79 & 7 & 21 & 10 & 1.800 \\
\hline
\end{tabular}

\section{PEMBAHASAN}

Hasil penelitian di Kawasan Hutan Lindung Reko Kecamatan Dabun Gelang Kabupaten Gayo Lues ditemukan sebanyak 38 jenis jamur makroskopis, diklasifikasikan kedalam 2 divisi, 7 ordo dan 19 familia. Jenis yang paling banyak ditemukan adalah ordo Polyporales dan Agaricales masing- masing sebanyak 16 jenis. Jumlah penelitian ini lebih banyak bila dibandingkan dengan hasil penelitian Khayati dan Hadi (2016) di Kawasan Lindung PKPH Sorong Selatan, yang hanya ditemukan 26 jenis jamur makroskopis yang diklasifikasikan kedalam 5 ordo dan 12 familia, untuk jenis jamur yang paling banyak ditemukan ialah ordo Polyporales.

Perbedaan penemuan dari kedua kawasan ini dikarenakan ketersediaan substrat tempat hidupnya yang berbeda. kawasan hutan Reko paling banyak ditemukan pada kayu mati dibandingkan tanah. Menurut Khayati dan Hadi, (2016) Jamur paling banyak ditemukan ialah pada substrat kayu mati. Akibat penebangan pohon banyak itensitas cahaya yang masuk menyababkan serasah tidak ternaungi sehingga tanah menjadi kering 
maka dari itu jamur dan organisme lain tidak dapat tumbuh.

Stasiun I (daerah yang mewakili kawasan kaki gunung) berada pada ketinggian $1.700 \mathrm{mdpl}$, terdapat 15 spesies, 9 familia dan 3 ordo. Faktor fisik yaitu suhu udara $26{ }^{\circ} \mathrm{C}$, kelembaban udara $65 \%$, pH tanah 6, suhu tanah $21^{\circ} \mathrm{C}$ dan kelebaban tanah 22\%. Menurut Amelia, dkk, (2017) itensitas cahaya yang banyak masuk dapat menyebabkan suhu meninngkat lebih panas sehingga menghambat pertumbuhan jamur.

Stasiun II (kawasan mewakili bagian lereng gunung) memiliki ketinggian 1.750 mdpl, ditemukan 24 spesies, 6 ordo dan 15 familia dengan faktor lingkungan fisik yaitu suhu $22{ }^{\circ} \mathrm{C}$, kelembaban udara $71 \%$, pH tanah 6,9, suhu tanah $17^{\circ} \mathrm{C}$, kelembaban tanah $10 \%$. Stasiun ini merupakan setasiun yang yang paling bagus dari stasiun lainnya. Hal ini sesuai dengan pernyataan Sinurat, dkk. (2016) Substrat atau habitat memiliki peran penting bagi pertumbuhan jamur sehingga tidak bisa dipisahkan dari jamur atau organisme lainnya. Dibandingkan dengan stasiun lain setasiun ini memiliki substrat yang paling bagus.

Stasiun III (kawasan yang mencakup puncak gunung) terletak pada ketinggian 1.800 mdpl, ditemukan berjumlah 18 spesies yang termasuk kedalam 3 ordo dan 10 familia. Faktor fisik lingkungan yaitu suhu udara $24^{\circ} \mathrm{C}$, kelembaban udara $79 \%, \mathrm{pH}$ tanah, 7 suhu tanah $21^{\circ} \mathrm{C}$, kelembaban tanah $10 \%$.

Karakteristik jamur makroskopis yang ditemukan di Kawasan Hutan Reko Kecamatan Dabun Gelang Kabupaten Gayo Lues sangat bervariasi mulai dari segi bentuk tudung, warna tudung, permukaan tudung, tepi tudung, bentuk lamela, warna lamela, letak tangkai, diameter, testur dan substrat. Bentuk tudung yang paling banyak ditemukan di kawasan tersebut ialah bentuk kipas dan payung. Bentuk kipas dan payung biasanya dapat ditemukan dengan mudah yaitu pada kayu mati.

Terdapat 38 spesies jamur yang telah diidentifikasi di Kawasan hutan lindung Reko Kecamatan Dabun Gelang Kabupaten Gayo Lues 5 spesies diantaranyan termasuk kedalam spesies jamur dapat dikonsumsi, 16 spesies jamur tidak dikonsumsi dan 2 spesies jamur beracun. Jumlah ini lebih sedikit bila dibandingkan dengan penelitian Taurina, (2019) di Kawasan Hutan Paya Rebol Kecamatan Bener Kelipah Kabupaten Bener Meriah, ditemukan sebanyak 5 spesies jamur yang dapat dikonsumsi, 21 spesies tidak dapat dikonsumsi dan 4 spesies jamur yang beracun.

Berdasarkan hasil identifikasi (Tabel 2), jenis jamur yang dapat dikonsumsi terdiri dari 5 spesies meliputi genus yakni Schizophyllum, Auricularia, Pleurotus, dan Lentinus. Untuk jamur yang tidak dikonsumsi terdiri dari 16 spesies meliputi Genus Daldiniacon, Coprinus, , Ganoderma, Amauroderma, Ganoderma, Earliellas, Pycnoporus, Microporus, Hexagonia, Trametes, Hexagonia, Perenniporia, Ceriporiopsis, Trametes, Daedaleopsis, dan Stereum.

Berdasarkan hasil identifikasi 5 spesies jamur dikonsumsi dan 16 spesies jamur makroskopis yang termasuk kedalam jenis jamur yang tidak dapat dikonsumsi hal ini dikarenakan pada beberapa jamur 
memiliki testur yang keras. Sedangkan untuk jamur beracun hanya terdapat 2 jenis saja.

Lima spesies jamur makroskopis dapat dikonsumsi ditemukan di lokasi penelitian dengan suhu $24-26^{\circ} \mathrm{C}$. Spesies jamur makroskopis genus Auricularia ditemukan 1 spesies berwarna coklat jamur Auricularia sangat disukai oleh masyarakat. Menurut Susan dan Atik (2017) sebagian besar masyarakat di Indonesia mengkonsumsi jamur jamur ini karena memiliki rasa yang enak hidup secara berkelompok memiliki tubuh buah berwarna coklat disertai dengan lipatan.

Genus Schizophyllum commune. Jenis jamur ini dikenal di beberapa daerah, seperti (Jawa) yaitu jamur grigit (Sunda) supa beas, (Sulawesi) kulat inditjeng, (Halmahera) ngawate, (Ternate) keho kaladede, dan (Tidore) keho dodole.

Genus Pleurotus ditemukan 1 spesies, jamur ini memiliki tudung berwarna putih dengan testur tudung lunak jika diraba permukaan tudung terasa halus. Menurut Susilawati dan Raharjo, (2010) jamur Pleurotus ini sangat tergantung pada faktor fisik seperti suhu $26-28^{\circ} \mathrm{C}$, kelembaban udara 80-90\% dan media tanam yang agak masam antara 5-6. Hasil wawancara dari masyarakat sekitar jamur Lentinus (shitake) banyak dimanfaatkan sebagai obat-obatan. Jamur Lentinus juga memiliki potensi sebagai senyawa antimikroba sehingga jamur ini dapat dimakan karena mengandung nutrisi yang baik (Sudirman, 2005).

Berdasarkan hasil wawancara dari masyarakat sekitar jamur Lycoperdon pyriforme atau sering disebut oleh masyarakat jamur bantal kukur ialah jenis jamur yang dapat dikonsumsi tetapi tidak semua masyarakat menyukai jamur ini hanya beberapa orang saja.

Jamur yang tidak dikonsumsi ditemukan 16 jenis hal ini dikarenakan pada beberapa jenis jamur memiliki testur yang keras dan tubuh yang berukuran sangat kecil. Hal ini sesuai dengan pernyataan Taurina, (2019) berdasarkan penelitian di Kawasan Hutan Paya Rebol Kecamatan Bener Kelipah Kabupaten Bener Meriah, ada beberapa jenis jamur yaitu tidak beracun tetapi tidak dikonsumsi dikarenakan testur yang jamur tersebut keras atau tidak lezat. Spesies jamur beracun ditemukan 2 spesies dari 2 genus yang berbeda yaitu Gymnopilus dan Marasmius tumbuh tersebar pada substrat tanah dan kayu mati suhu berkusar antara 22-26 ${ }^{\circ} \mathrm{C}$ genus Gymnopilus ditemukan tumbuh pada substrat kayu mati dengan suhu $22-24{ }^{\circ} \mathrm{C}$ dan genus Marasmius ditemukan pada substrat tanah dengan suhu $22-24^{\circ} \mathrm{C}$. jamur dari genus Gymnopilus ditemukan 1 spesies yaitu Gymnopilus fulgens memiliki tudung payung berwarna oranye dengan bagian tengah berwarna hitam, permukaan tudung halus, tepi tudung halus tidak bergaris jamur ini memiliki diameter tudung berukuran 2-4 $\mathrm{cm}$, bentuk lamella bercabang dari tepi, warna lemella hitam dan memiliki letak tangkai dibagian tengah. Testur jamur ini lunak dan terdapat pada kayu mati Menueut Heolec, (2005) jamur Gymnopilus fulgens memiliki pileus berwarna cerah oranye-kuning atau oranye-berkarat sampai merah, spora berukuran $8-11 \times 5-7 \mathrm{~cm}$, habitat rawa gambut atau di tanah gambut. 
Genus Marasmius yaitu Jamur Marasmius androsaceus ini memiliki bentuk tudung seperti payung, warna tudung putih ditengah ada lingkaran merah kecoklatan, permukaan atas tudung kaku, lamela teratur. Warna lamela putih dan letak tangkai dari tengah, berdiameter 0,4-1 cm, bertestur lunak, terdapat pada tanah. Menurut Hasanuddin (2014) jamur Marasmius androsaceus bertudung dan berbentuk rata dengan permukaan berkerut, spesies jamur ini tidak bisa dimakan karena mengandung racun.

\section{KESIMPULAN}

1. Spesies jamur yang ditemukan di Kawasan Hutan Lindung Reko Kecamatan Dabun Gelang Kabupaten Gayo Lues, berjumlah 38 spesies yang terdiri dari 2 divisi, 7 ordo dan 19 familia.

2. Berdasarkan identifikasi terdapat 5 spesies jamur dikonsumsi yaitu Auricularia aulicular-judae (Bull) J.Schr, Schizophyllum commune Fr, Pleurotus ostreatus Jacq. P. Kummer, Lycoperdon pyriforme Schaef, dan Lentinus sp. (L), 16 spesies tidak dikonsumsi dan 2 spesies beracun yaitu Gymnopilus fulgens (J. Favre \& Maire) Singer, dan Marasmius androsaceus (L) Fr.

\section{Saran}

1. Perlu dilakukan uji lebih lanjut mengenai jenis jamur yang dapat dikonsumsi dan jenis jamur beracun.

2. Diharapkan peneliti selanjutya dapat meneliti seluruh Kawasan Hutan Lindung Reko Kecamtan Dabun Gelang Kabupaten Gayo Lues, khususnya kawasan hutan primer untuk mendapat hasil yang beragam dan data yang lebih akurat.

\section{DAFTAR PUSTAKA}

Amelia, F., Michel, Klerenita, M.G., dan Jose, F., Indah, J. 2017. Pengaruh Suhu dan Itensitas Cahaya Terhadap Pertumbuhan Jamur Tiram di Tangerang. Biogenesis: Jural Ilmiah Biologi, 5 (1):1-6.

BPS Kabupaten Gayo Lues.2019. https://gayolueskab.bps.go.id. Diakses 19 Juli 2020.

Hasanuddin. 2014. Jenis Jamur Makroskopis Sebagai Media Pembelajaran Biologi (Studi Di TNGL Blangjerango Kabupaten Gayo Lues). Jurnal Biotik, 2 (1): 1-76.

Hidayati, H, R.M., dan Asmawati. 2015. Pemanfaatan Serat Tanda Kosong Kepala Sawit Sebagai Media Pertumbuhan Jamur Tiram Putih. BIOPROPAL INDUSTRI, 6 (2): 73-80.

Holec, J. 2005.The Genus Gymnopilus (Fungi, Agaricales) in The Czech Republic With Respect To Collection From Other European Countries. National Museum, Mycological Depaterment, 1 (2): 1-52.

Khayati, L., dan Hadi, W. 2016. Keanekaragaman Jamur Kelas Basidiomycetes di Kawasan Lindung KPHP Sorong Selatan. Prosiding Symbion (Symposium on Biology Education). Prodi Pendidikan Biologi, FKIP:Universitas Ahmad Dahlan.

Parjimo dan Andoko, A. 2007. Budidaya Jamur. Jakarta: Agromedia Pustaka.

Sinurat, E. B., Endang, D., dan Khoiron, N. 2016. Jenis-Jenis Basidiomycota di Area Air Terjun Curug Embun Kota Pagaralam dan Sumbanganya 
pada Pelajaran Biologi di Sma. Jurnal Pembelajaran Biologi, 3(1): 35-48.

Sudirman LI. 2005. Deteksi senyawa antimikrob yang diisolasi dari beberapa Lentinus tropis dengan metode bioutografi. Hayati 12: 67-72..

Susan, D. dan Atik, R. 2017. Catatan Beberapa Jamur Makro dari Pulau Enggano: Diversitas dan Potensinya. Jurnal Ilmu-ilmu Hayati, 16(3): 243-255.

Susilawati, B. Raharjo. 2010. Petunjuk Teknis Budidaya Jamur Tiram (Pleourotus ostreatus var florida) yang ramah lingkungan. (Materi Pelatihan Agribisnis bagi KMPH). Report No. 50.STE. Final. Palembang.

Taurina, D. 2019. Keanekaragaman Jenis Jamur Makroskopis Yang Terdapat Di Kawasan Hutan Paya Rebol Kecamatan Bener Kelipah Kabupaten Bener Meriah. Skripsi. Banda Aceh: Universitas Syiah Kuala.

Widhiastuti, R., dan Nurtjahja, K. 2013. Biodiversitas dan Indentifikasi Cendawan d i Tanaman Wisata Alam Sibolangit dan Sicikehcikeh Sumatra Utara. Self Publishing. Medan. $100 \mathrm{Hal}$.

www.fungikingdom.net. Featuring mycology lessons and mushroom photography by Dianna Smith and a sries of mycology articles by Bill Bakatiti. Diakses 9 November 2020

www.gbif.org. Global Biodiversiti Information Facility. Diakses 25 januari 2021 